Centenary of Plastics 1862-1962. It was at the International Exhibition in London in 1862 that Alexander Parkes showed for the first time to the public "a new material and manufacture which from its valuable properties had induced the inventor to patent the discovery in England and France and to devote his attention for the last 10 years to the development of the capabilities and application of this beautiful substance to the Arts". In the case shown at the Exhibition were a few illustrations of the numerous purposes for which, according to Parkes, 'Parkesine' might be applied. These included medallions, salvers, hollow ware, tubes, buttons, combs, knife handles, pierced and fret work, inlaid work, bookbinding, card cases, boxes, pens, penholders, etc. Parkes received a prize medal for his exhibit. 'Parkesine' contained no camphor, an indispensable component of the later material celluloid, and while Parkes mentioned camphor in his patent of 1865 he did not appreciate its unique properties. There can be no doubt, however, that 1862 saw for the first time the material which led directly to the modern form of celluloid. The programme to be organized by the Joint Committee will include open days in firms in the plastics industry and special meetings and lectures throughout the centenary year (1962-63), culminating in the International Plastics Exhibition to be held at Olympia during June 12-22. 1963.

\section{Personnel Management Salaries}

During the summer of 1956 the Institute of Personnel Management carried out a survey of salaries paid to members. This was undertaken because the Institute had been frequently asked by individual members, and by companies filling vacancies, about salaries paid to personnel officers and other members of personnel departments. To collect this information, questionnaires were sent to companies throughout Britain and senior personnel officers were asked to complete these on behalf of their personnel staff. A report based on this survey was issued at the beginning of 1957. This report proved to be of great value both to individual members and also to companies filling vacancies or setting up personnel departments. The Institute has now taken a further and more extensive survey to obtain an up-to-date review of members' salaries in Britain (Personnel Management Salaries: Report of a Survey undertaken in February/March 1961. Pp. 32. London: Institute of Personnel Management, 1961. 21s.). Of the 2,900 questionnaires sent out to practising personnel officers, approximately 1,250 questionnaires were returned, of which 1,222 were included in the final analysis. The personnel officers completing the questionnaire can be regarded as representative of the Institute members as a whole. The report consists of eighteen tables which give salaries paid under a number of different headings, including salaries according to positions held, age group, type of company, industry, area, length of time with the firm, and number of employees.

\section{The National Mineral Collection, Ottawa}

A Natronac Mineral Collection, containing specimens from Canada and all over the world, has been established at Ottawa through the co-operation of two Federal Government departments. The Collection will consist of two series: a systematic reference series to be maintained by the Geological Survey of Canada, within the Department of Mines and Tech- nical Surveys, with H. R. Steacy as curator, and a display series, in the National Museum, under the curatorship of Colonel E. Taylor. The Museum is within the Department of Northern Affairs and National Resources. A single catalogue, to be prepared and maintained by the Geological Survey, will cover the whole Collection. Both Departments already possess substantial collections of minerals. accumulated since the Geological Survey was formed in 1842. The number of specimens in the keeping of the Survey is estimated at 50,000. Among them are rare gold nuggets and precious stones, as well as large pieces of silver - one of them $3 \frac{1}{2} \mathrm{ft}$. long-found by geologists, prospectors, and mining crews in many parts of Canada. The curators of both series will endeavour to expand and to improve their series year by year. The Collection now has specimens representing about 30 per cent of the world's known mineral types - a valuable aid to training and research in geological science and exploration.

\section{Recent Developments in Medical Treatment}

A wELCOME sign of how clinicians are adapting themselves to the changing outlook in medicine is shown in the current issue of the Practitioner (187, No. 1120; October 1961). This is a special issue dealing with advances in treatment, and three of the contributors do not concern themselves with 'treatment' in the narrow sense of the term. The contributors in question deal with advances in pædiatrics, general practice, and public health, the inclusion of the latter subject indicating that preventive medicine is an integral part of the practice of medicine. The reasons why the other two subjects have been dealt with in a particular way are given by the contributors themselves. "The Holistic conception of child life within the family circle", according to Prof. W. S. Craig, "is fundamental to pædiatric thought, and a knowledge of human relations, and of the art of consultation and physical examination, must continue to provide the foundations of pæediatric teaching". "Too often", according to Dr. Richard Scott, "advance is halted by our failure to apply existing knowledge. It would appear that, as in many other spheres, so also in medicine are we more skilful in advancing knowledge than in applying it". That 'treatment', in the narrower sense of the term, is not overlooked is well exemplified by the other fifteen articles in the symposium.

\section{The Perkin Centenary Trust: Awards}

Applications for the awards of the Perkin Centenary Fellowship and Scholarships are invited by the Trustees. The Perkin Centenary Fellowship is offered for one or two years for the purpose of higher study of any subject approved by the Trustees. Candidates will be required to show either that they have had experience in an industrial firm or other institution concerned in the manufacture or the application of colouring matters, or that their intended field of study has a direct bearing on these subjects. The value of the Fellowship is $£ 750$ per annum with an additional grant of up to $£ 100$ per annum towards certain designated expenses. It is tenable, from October 1962, at any university, technical college or other institution approved by the Trustees. The Perkin Centenary Scholarship: two such awards are offered, each for two years, to enable candidates employed in an industrial firm or other institution concerned with the manufacture or the application of 